\title{
Erratum to: Global Mobile Satellite Communications Theory
}

\section{Erratum to:}

S.D. Ilčev, Global Mobile Satellite Communications Theory, DOI 10.1007/978-3-319-39171-7

The book was inadvertently published without removing the mention of Volume 1.

The erratum book has been updated with the change.

The updated original online version for this book can be found at 10.1007/978-3-319-39171-7

S.D. Ilčev (ه)

Durban University of Technology (DUT), Durban, South Africa

e-mail: ilcev@dut.ac.za 